\title{
PRINCIPLES IN POWER
}


A volume in the series

\section{The United States in the World}

Founded by Mark Philip Bradley and Paul A. Kramer

Edited by Benjamin Coates, Emily Conroy-Krutz, Paul A. Kramer, and Judy Tzu-Chun Wu

A list of titles in this series is available at www.cornellpress.cornell.edu. 


\section{PRINCIPLES IN POWER}

\section{Latin America and the Politics of U.S. Human Rights Diplomacy}

\section{Vanessa Walker}




\section{Copyright (C) 2020 by Cornell University}

All rights reserved. Except for brief quotations in a review, this book, or parts thereof, must not be reproduced in any form without permission in writing from the publisher. For information, address Cornell University Press, Sage House, 512 East State Street, Ithaca, New York 14850. Visit our website at cornellpress.cornell.edu.

First published 2020 by Cornell University Press

Library of Congress Cataloging-in-Publication Data

Names: Walker, Vanessa, 1978- author.

Title: Principles in power : Latin America and the politics of U.S. human rights diplomacy / Vanessa Walker.

Description: Ithaca [New York] : Cornell University Press, 2020. | Series: The United States in the world | Includes bibliographical references and index.

Identifiers: LCCN 2020017808 (print) | LCCN 2020017809 (ebook) | ISBN 9781501713682 (cloth) | ISBN 9781501752681 (epub) | ISBN 9781501752698 (pdf)

Subjects: LCSH: Human rights-Government policy-United StatesHistory-20th century. | Human rights—Latin America-History20th century. | Human rights advocacy-United States-History-20th century. | United States-Foreign relations-Latin America. | Latin America-Foreign relations-United States. | United States-Foreign relations-1945-1989.

Classification: LCC JC599.U5 W285 2020 (print) | LCC JC599.U5 (ebook) | DDC 323.098-dc23

LC record available at https://lccn.loc.gov/2020017808

LC ebook record available at https://lccn.loc.gov/2020017809

Cover photographs: Top, on August 30, 1977, President Jimmy Carter met with civic leaders from Georgia and Florida at the White House to explain his new Panama Canal treaty. On August 12, 2015, Carter announced he had cancer and would undergo treatment at an Atlanta hospital. (AP Photo/Harvey Georges); bottom, Demonstrators protest the killing of former Chilean ambassador Orlando Letelier during a rally in Washington, DC, September 26, 1976. Letelier and Ronni Karpen Moffitt were killed in a car bombing. (AP Photo/John Duricka) 


\section{For Adi}


If human rights is to be a central factor in the policy debate, the significance of non-governmental bodies is absolutely essential. I think the important thing to say about states and about human rights is that the action of states should neither be underestimated or overestimated. They should not be underestimated; you cannot ignore them in the struggle for human rights, what they do will count for good or ill. But the significance of states should not be overestimated. Our faith in the State is always tenuous, and rightly so. Our faith in the modern bureaucratic state should be fragilely placed. They need to be contained, restrained, pressured, shaped and directed from the outside. ... What we try to do when we attempt to impose human rights criteria on other forms of power-political, economic, military-in the foreign policy equation, is we seek to use the very fragile instrument of moral suasion, the fabric of moral sinew, to control and contain the power of the modern state.

—Father J. Bryan Hehir, Seventh Annual Letelier-Moffitt Memorial Human Rights Award Ceremony, September 20, 1983 